\title{
Varoluşçu Psikoterapi (I. D. Yalom)
}

\author{
Tuğba BAKIRTAŞ*
}

\author{
Varoluşçu Psikoterapi \\ (Existential Psychotherapy) \\ Irvin D. Yalom \\ çev: Zeliha İyidoğan Babayiğit \\ Kabalacı Yayıncılık, İstanbul 2011, 756 sayfa
}

\section{$\S \S \S$}

Kitap, Stanford Üniversitesi Tıp Fakültesi'nde psikiyatri profesörlüğü yapmakta olan Rus kökenli Yahudi asıllı ABD'li profesör Irvin D. Yalom'un 1980 yılında doktora tezi olarak hazırlamış olduğu eserin Türkçe'ye çevrilmiş halidir. Birçok popüler esere imza atmış olan Yalom ünlü bir psikoterapisttir. En popüler eseri de Nietzche Ağladığında'dır.

Yazarın burada değerlendirilmeye alınacak kitabı; "1. Kısım: Giriş, 2. Kısım: Ölüm, 3. Kısım: Özgürlük (Sorumluluk ve İsteme), 4. Kısım: Varoluşsal Yalıtım, 5. Kısım: Anlamsızlık" kısımlarından oluşmaktadır. Genel olarak kitap varoluşçu problemlerle nasıl baş edileceğini göstermeye çalışmaktadır. Yazarın bu kitap ile üzerinde durduğu dört nihai kaygı bulunmaktadır: Ölüm, özgürlük, yalıtım ve anlamsızlık. Eser, bu kaygıları içeren dört bölümden ve bunların alt kısımlarından oluşmaktadır.

Varoluşsal kaygılar, isminden de anlaşılabileceği gibi yaşam ve ölüm arasında sıkışıp kalan, insanoğlunun baş etmeye uğraştığı problemleridir. Bu problemler hayatın her döneminde, her insanın farklı ya da benzer şekillerde baş etmek zorunda kaldıkları sorunlarıdır. Varoluşçu psikoterapi de bireyin var

* Sakarya Üniversitesi Sosyal Bilimler Enstitüsü Felsefe ve Din Bilimleri Anabilim Dalı (Din Psikolojisi) Yüksek Lisans Öğrencisi, e-posta: sautuba@gmail.com (ORCID: 0000-00018371-8613) 
olmasından kaynaklı endişe ve problemlerine odaklanan dinamik bir terapi yaklaşımıdır. Nietzsche "Neden yaşadığını bilen kişi her durumda hemen her şeye katlanabilir" demektedir. Bu sözüyle o, hayatın anlamlı olmasına dikkat çekmekte ve bireysel problemlerin hayat için önemini ifade etmeye çalışmaktadır. Günümüz modern insanı için hayatın anlamını ifade etmek ise oldukça zor gözükmektedir. Kendini dünyadan soyutlayan, teknolojinin kurbanı olan, bireysel bir hayat yaşayan ve yalnız hisseden, bu yalnızlıktan dolayı kaygı duyan modern insanlar ise varoluşsal problemlerle iç içedir ve varoluşçu yaklaşımın ana hedefindedir.

Yalom kitabında varoluşçu korku kaynaklarının tanıdık olduklarını vurgular, çünkü onlar herkes tarafından az ya da çok bilinmektedir, varoluş anksiyeteleri de kendini hayatın her anında gösterebilmektedir. Varoluşçu bir terapist olarak terapi sürecini asıl başarılı kılan şeyin teknik müdahale ya da stratejik yöntemlerden ziyade terapistin işin içine kattığı sevgi, şefkat, özen gösterme gibi "ufak dokunuşlar" olduğunun altını çizmektedir. Onun kitabı kaleme almadaki asıl amacı da bu tür problemlerin üstesinden nasıl gelinebileceğini göstermek ve birey için anlamlı, huzurlu bir hayatın gelişmesine katkı sağlamaktır. Asıl hedefi, insanın geçmişini derinlemesine araştırma amacı gütmeden günlük kaygılar ile uğraşmaktır.

Yalom birinci bölümde ayrıntıı bir şekilde ölüm, ölüm anksiyeteleri, çocuklarda ölüm ve psikoterapik yöntemler üzerinde durmaktadır. Ölüm hayatın bir gerçeğidir. Manilius "Doğumda bile ölürüz; son başlangıçta vardır" demekte ve ölüm gerçeğine dikkat çekmektedir. Hiedegger ise var olmayı unutma durumu ile var olmayı düşünme durumu olarak nitelendirdiği dünyada iki varoluş olduğunu vurgulamaktadır. Ölüm insan için var olmayı düşünmeye sevk eden en önemli kaynaklardan bir tanesi olarak karşımıza çıkmaktadır. Yazar kitabında ölüm kadar hayatımızı anlamlı kılan ve eşi benzeri olmayan bir şey daha yoktur demektedir. Ölümün fizikselliği insanı tahrip etse de ölüm fikri onu korumakta, hayatının amacını kavratmakta ve yaşamı güzelleştirmektedir.

Yalom'un üstünde dikkatle durduğu bir diğer konu ise ölümle yüzleşmenin kişisel değişime olan katkısıdır. Ölüme yaklaşmak insanlar üzerinde olumlu etkiler yapmaktadır. Hayat önceliklerini yeniden düzenlemek, özgürlük, yapmak istemediklerini yapmamak, hayatı güçlü bir şekilde yaşamak, hayatın gerçeklerini kabul etmek bunların sadece bazılarıdır. Yalom burada şu soru ile ölümün insanlar üzerindeki etkisine de dikkat çekmektedir: "Olumlu bir kişisel değişimin ölümle yüzleşmenin ardından gelmesi ne kadar da yaygın"? Gerçekten de yaşamak için ölmek gerekir fikrine katılmamak imkânsız gibi görü- 
nüyor. Schmitt'in de dediği gibi “yaşamaya başlamadan önce ölümün gözlerinin içine bakmak zorunda kaldım. Yaşamak için ölmek gerekiyordu”.

Yalom, ölüm anksiyetelerinin insan hayatı için ne kadar önemli olduğunu vurgulamaktadır. Hayatın büyük bir kısmı ölümü inkâr etmek ile geçer demektedir. Aslında insan yaşarken ölümden o kadar çok korkmaktadır ki ölümsüzlük fikrine ulaşabilmek için her yolu denemektedir. Biyolojik olarak var olma çabası, dinsel olarak ölümden sonraki yaşam arzusu, sanat eserleri ile var olabilme gayreti, yaşamın aşkınlığı fikri gibi tezahürleri bunun en açık göstergesidir de denilebilir.

Yazar tüm bunlardan hareketle ölümle nasıl baş edilebileceğini gösteren bir terapi yöntemi uygulamak istemektedir. Her ne kadar baş edilmesi zor bir mesele olsa da insan hayatını anlamlı kılabilmek için, bastırımış ölüm korkusu ve anksiyeteleri ile baş edebilmek için varoluşçu terapiye ne kadar intiyaç duyulduğuna dikkat çekmektedir.

İkinci bölümde ise özgürlük konusuna değinmekte, sorumluluk ve irade kavramlarını ele alarak bunları bireyin varoluşsal problemleri açısından değerlendirmeye tabi tutmaktadır. Bir kişinin özgür olabilmesi kendi sorumluluğunu üstlenebilmesi, davranışlarına kendisinin yön vermesi, dilediğini ve istediğini yapabilmesi, başkasından sorumluluğunu almasını istemenin dahi bir sorumluluk olduğunu vurgulamaktadır. Kendilerini "istemiyorum ya da yapamam" şeklinde ifade eden hastalarına "yapmayacağım" kelimesini kullanmalarının sorumluluk açısından daha doğru bir kavram olduğunu hatırlatmaktadır. Özgürlük ve dahi sorumluluktan kaçış bireyin kendinden ve dünyadan kaçması anlamına gelmektedir. Sartre'nin de dediği gibi: “Insan kendi hayatından tamamen sorumludur. Yalnızca hareketlerinden değil hareket etmediklerinden de sorumludur" der. Sorumluluğun kapsamını net bir şekilde göstermesi bakımından bu söz önem taşımaktadır. Zorlantı, inkar, sorumluluğun yer değiştirmesi, sorumluluktan kaçma, karar verme bozuklukları; bunların hepsi sorumluluk anksiyeteleridir ve bireye bunlarla nasıl baş edilmesi gerektiğini göstermek gerekmektedir.

Sorumluluk kadar önemli bir diğer konu ise dilemek ve istemektir, çünkü bu kavramlar sorumluluk ile doğrudan bağlantılıdır. Bir eylemi yapmayı dilemeden ya da istemeden onu gerçekleştirmek imkânsızdır. Aritoteles "isteme eylemden önce gelen arzudur" der. Dileme ve isteme, kararlılık ve bağlılık açısından önem taşımaktadır. Bazı kişilerde istence karşı var olan direnç ya da sorumluluk üstlenmeme arzuları ile terapist doğru bir şekilde baş etmesini bilmelidir. Hastanın istencini kırmada, sorumluluk almaya istekli olmada, ona 
yol göstermede, karasızlığının ya da istençsizliğinin bedelini yine kendisinin ödeyeceğini göstermede rehber olmalıdır.

Üçüncü bölümde ise Yalom varoluşsal yalıtım kavramı üzerimde durmaktadır. İnsanın doğuştan varoluşsal yalnızlık içine doğduğunu, bu yalnızlık duygusu ile baş edebilmek için çeşitli anksiyeteler geliştirdiğinin altını çizmektedir. $\mathrm{O}$, bireyin yaşamının gayesine varmasını sağlamaya yardımcı olacak ve yalıtılmışlık duygusundan kurtaracak yegâne gücün sevgi olduğunu belirtmektedir. Sevgi, bebeklikten itibaren en yoğun hissedilen duydudur. Sevilme ile başlar, sevme ile sonuçlanır. Birey yalnız olmadığını ilk ailesi sayesinde algılar, arkadaşları, çevresi, komşuları, eşi, çocukları ve mesai arkadaşları bu durumu pekiştirir. Ancak insan olgun sevgi kabiliyetine ulaşabilirse mutlu olabilir. Aksi takdirde narsizmden hiçbir farkı kalmaz, bencil yönelimler hayatı ele geçirmiş olur. Yalom, varoluşsal yalıtımın altını çizerken en çok da ölüm, sorumsuzluk, yalnızlık, intihar vb. şekilde kendini ortaya çıkardığını vurgulamaktadır. Birey hayatının anlamını kavrayabilmek için kendi sorunları ile nasıl baş edebileceğini öğrenmesi gerekmektedir. İşte burada terapist devreye girerek hayatı anlamlı kılmaya çalışır.

Dördüncü bölümde Yalom, anlamsızlık kavramı üzerinde durmaktadır. İnsanın modern dünyada baş etmek zorunda kaldığı pek çok problemle karşı karşıya kalmasına rağmen hatta anlamsızlık duygusunun bütün bedenini kaplamasına rağmen hayat amacının farkına varmasının ve anlamlı bir yaşam sürmesinin kişiyi hayata bağladığına değinmektedir. Kozmik bir dinsel amacın ya da dünyevi bir anlam intiyacının bireyi anlamsızlıktan kurtardığını ifade etmektedir. Varoluşçu bir terapist olarak Yalom, anlamsızlık kaygısıyla baş etmeye çalışan hastalarına, hayatın anlamını kavratabilmeyi ve onları bu yaşamda mutlu edebileceğini düşündüğü alanlara yönlendirerek rehber olmaktadır.

Kitap, genel hatları ile değerlendirilecek olursa, dört nihai varoluşsal kaygıya karşı terapi yöntemleri ve çözüm önerileri gösterilmeye çalışılmaktadır. Yalom, her ne kadar iyi bir terapist olsa da ve varoluşsal kaygılardan olan ölüm, özgürlük, yalıtım ve anlamsızlık ile nasıl baş edilmesi gerektiğini açıklasa da terapisinde dini göz ardı etmesi ve insanın yüce bir varlığa bağlanma intiyacını dikkate almaması bir eksiklik olarak değerlendirilebilmektedir.

Varoluşsal kaygıların başında olan ölüm; ahret hayatı, cennet ve cehennem olgusu, bu dünyada yaptıklarının hesabını vereceği düşüncesi ile şekillenirse bireyi anlamlı bir yaşama hazırlamaktadır. Ancak Yalom, varoluş- 
sal bu problem karşısında yine varoluşsal bir çözüm önerisi olan dini görmezden gelmektedir.

Aynı şekilde özgürlük, sorumluluk, istenç, yalnızlık ve anlamsızlık gibi kaygılar da din ile birlikte düşünüldüğünde anlamlı hale gelmektedir. Yalom, iyi bir terapist ve bireyi içinden çıkılması pek çok problemden ustaca kurtarmasına karşı bu din konusundaki eksikliği ve görmezden gelme düşüncesi, onun tedavi yönteminin eksikliğini göstermektedir.

Yalom, varoluşsal kaygıları felsefik temellerinden koparmadan ele almaktadır. Aynı zamanda bir ruh sağlığı uzmanı olması nedeniyle de varoluşsal kaygıları daha çok psikoloji bilimi bağlamında incelemekte ve çözümler üretmeye çalışmaktadır.

Burada şunu da izah etmek gerekir ki hiçbir terapist hastalarına herhangi bir din, dini tutum ya da davranışla ilgili olumlu ya da olumsuz telkinde bulunamaz ve bulunmamaları da gerekmektedir. Yalom da mesleği gereği bu hususta tarafsız kalmayı tercih etmektedir. Ancak inanılan ve belli bir kutsallığı olan şeyin de bu şekilde görmezden gelinmemesi gerekir.

Ancak Yalom'un kullandığı dil, hastaları ile olan iletişim biçimi, ne olursa olsun dürüstlükten ayrılmama prensibi, terapide olaya müdahale etmeyip sadece rehber konumunda kalabilmesi, hastalarının kendi çözüm yollarını kendilerinin bulmasına liderlik yapması onu kendisi gibi olan diğer terapistlerden ayrıcalıklı bir konuma yükseltmektedir. 